\title{
THE ENIGMA OF LEWY BODY DEMENTIA: A CASE REPORT
}

\author{
Ivona Orlović ${ }^{1}$, Matija Bartolović ${ }^{1}$, Katarina Marušić ${ }^{1}$, Darko Vlahović ${ }^{1}$, \\ Ines Šiško Markoš2, Dalibor Karlović ${ }^{1,3,4}$ and Vjekoslav Peitl ${ }^{1,3}$ \\ ${ }^{1}$ Department of Psychiatry, Sestre milosrdnice University Hospital Centre, Zagreb, Croatia; \\ ${ }^{2}$ Department of Oncology and Nuclear Medicine, Sestre milosrdnice University Hospital Centre, Zagreb, Croatia; \\ ${ }^{3}$ Catholic University of Zagreb, Zagreb, Croatia; \\ ${ }^{4}$ School of Dental Medicine, University of Zagreb, Zagreb, Croatia
}

\begin{abstract}
SUMMARY - Lewy body dementia is a progressive neurodegenerative disease and is considered to be the second most common cause of dementia in the elderly. Because of the complexity of clinical presentation, it is often misdiagnosed and mistaken for other dementias, which may result in administering inappropriate therapy, and thus worsening of the patient condition. We reviewed a case of a 71-year-old patient whose clinical presentation gradually occurred with complex visual hallucinations, atypical extrapyramidal motor symptoms, fluctuating cognitive impairments with delirious episodes, and oscillating syncope. Depressive mood, impaired daily functioning and sensitivity to antipsychotics were also noted. Extensive diagnostic workup was performed with neuropsychological testing and use of single-photon emission computerized tomography. Considering the clinical presentation and diagnostic procedures performed, the diagnosis of Lewy body dementia was set and pharmacotherapy was revised. We discuss the importance of taking overall clinical presentation and diagnostic treatment in consideration and applying appropriate therapy to slow down the progression of the disease and exacerbation of the patient's psychological functions.
\end{abstract}

Key words: Lewy body disease; Cognitive dysfunction; Hallucinations; Parkinsonian disorders; Cholinesterase inbibitors; Dementia

\section{Introduction}

Lewy body dementia (LBD) is a progressive neurodegenerative disease that is considered to be the second most common cause of dementia after Alzheimer's disease $(\mathrm{AD})^{1,2}$. Usually, it is clinically and pathologically overlapping with Parkinson's disease dementia (PDD) or with AD, making it difficult to identify and differentiate in a timely manner ${ }^{3,4}$. The disease starts gradually, usually in the seventh decade, it is twice as common in men and can be initially presented with dementia or parkinsonism, although patients de-

Correspondence to: Assist. Prof. Vjekoslav Peitl, MD, PhD, Department of Psychiatry, Sestre milosrdnice University Hospital Centre, Vinogradska c. 29, HR-10000 Zagreb, Croatia

E-mail: vjekoslav.peitl@gmail.com

Received July 11, 2019, accepted November 12, 2019 velop both clinical pictures over time ${ }^{5}$. LBD is characterized by cognitive fluctuations, behavioral REM sleep disturbance, early occurrence of visual hallucinations, and less frequently, by auditory hallucinations or delusions ${ }^{1}$. Parkinsonism in LBD differs somewhat from that in Parkinson's disease, but due to nonspecificity, LBD is diagnosed when cognitive impairment precedes parkinsonism or occurs within a year of the appearance of extrapyramidal symptoms ('one-year rule') $)^{3}$. In addition, significant autonomic dysfunction is present in more than half of the patients ${ }^{6}$, with frequent comorbid anxiety and depression ${ }^{7}$. Among other things, pronounced sensitivity to antipsychotics, especially dopamine antagonists, is clinically very important in recognizing $\mathrm{LBD}^{8}$.

Although the diagnosis of LBD can be confirmed with certainty only by autopsy of brain tissue, apart 
from basic clinical features, differentiation of the diagnosis is possible using magnetic resonance imaging (MRI) and single-photon emission computerized tomography (SPECT), i.e., a finding of temporoparietal and occipital hypoperfusion with reduced uptake of the striatal dopamine transporter ${ }^{3}$.

In this paper, we review a case of a man whose clinical presentation, hypersensitivity to antipsychotic therapy and diagnostic findings led us to suspect LBD. Our aim was to show the complexity of diagnosing LBD due to nonspecificity of various symptoms, which may result in the administration of inappropriate therapy and deterioration of clinical presentation, and thus of the patient condition.

\section{Case Report}

A 71-year-old patient, a retired sailor, married, father to three children, was admitted to the hospital for diagnostic check-up and treatment of organic hallucinosis and mildly manifested extrapyramidal symptoms. He was unburdened with neuropsychiatric heredity. The patient described extrapyramidal disorders as initial symptoms, which had begun to appear two years after retirement (fifteen years before). At first, he was treated with pramipexole dihydrochloride monohydrate. Visual hallucinations then started to appear and every day he saw a person he knew but it was not real. Parkinson's disease was diagnosed based on the persistence of extrapyramidal symptoms and was treated with a combination of levodopa and carbidopa. It resulted in intensified visual hallucinations, and the patient described it as seeing the crew and ships. Shortly before hospitalization, the patient was examined at a psychiatric outpatient clinic and was diagnosed with organic hallucinosis and a depressive episode. Escitalopram and olanzapine were introduced in therapy but the patient did not adhere to treatment recommendations. In the last two years, the patient experienced hypotensive episodes and syncope that led to the diagnosis of a cervical syndrome. At the same time, the patient experienced deterioration of daily functioning with a marked decline in decision making. Previously, he was treated for syphilis and suffered from asthma and gout. During the examination, he complained of frequent urination and constipation. He denied taking any psychoactive substances.
On the day of hospital admission, the patient was occasionally disoriented, he responded with short latency, along with psychomotor slowing with noticeable choreiform movements of the body, predominantly of the head, torso and arms. Also, cogwheeling effect and lead-pipe resistance were mildly indicated. He appeared to be hypothymic with weak affective modulation and pronounced intrapsychic tension. His thought flow was mildly slowed without any delusions in the thought content. He confirmed complex visual hallucinations which he described in detail with affective engagement. In the domain of personality, he seemed inclined to suppression and projection with occasionally reduced tolerance to external frustration. The patient's cognitive functions fluctuated throughout the day, primarily with impairment of executive functions (positive Luria's test).

Neurological testing revealed dysarthria, bradykinesia, hypomimia and elevated muscle tone of extrapyramidal type in all extremities, without loss of sensation. In Romberg's position, there was latero- and retropulsion, while walking was characterized by smaller steps.

Routine laboratory check-up revealed no significant deviations. Brain CT, which was performed due to frequent oscillations of consciousness and syncope, excluded acute neurological events, as well as any sort of an expansion process. Brain MRI showed diffuse atrophic changes of the brain with widening of the subarachnoid fluid space and brain sulci in frontoparietal and temporo-occipital region and atrophic changes of the cerebellum with expanded pericerebellar fluid spaces. There was absence of the representation of both putamina and the left nucleus caudatus, while the accumulation in the right nucleus caudatus was relatively maintained on the SPECT scan with 123-I ioflupane (Fig. 1). Basal brain activity was elevated along with severe functional impairment of the striatal dopamine system. Serologic testing excluded HIV dementia while reactive quantitative TPHA test for syphilis was positive. However, due to history data on previously treated syphilis, differential diagnosis of neurosyphilis was excluded. Neurologically determined anosmia was differentiated as a condition that occurred due to postinfectious neuritis along with subsequent permanent damage to the olfactory nerve. Neuropsychological testing using the instruments of clinical interview, WB II Verbal Part, WB Memory Scales, FAS and Rey Complex Figure Test revealed impaired verbal fluency, 


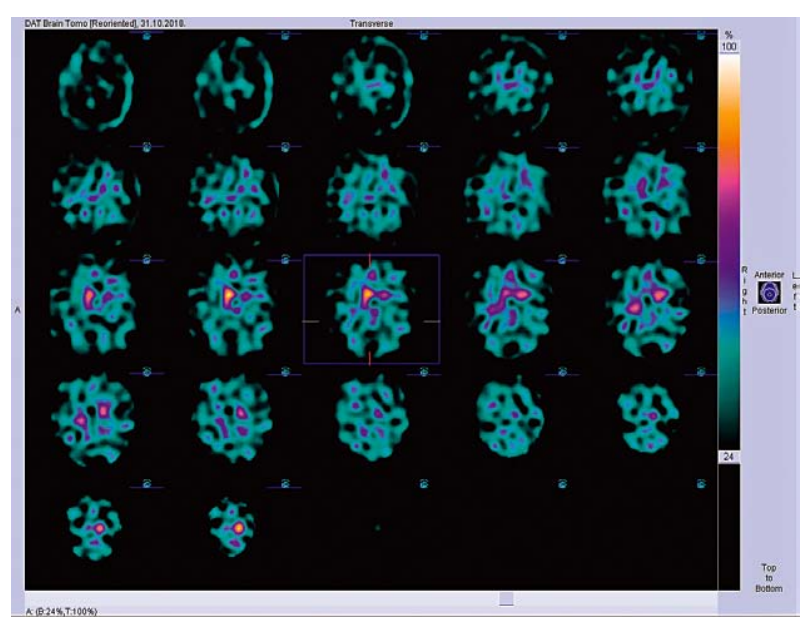

Fig. 1. SPECT scan with 123-I ioflupane showing elevated basal brain activity, along with severe functional impairment of the striatal dopamine system.

decreased memory and learning ability, reduced visualmotor abilities, and concentration disturbances.

Considering the diagnostic workup performed (clinical signs and neuroradiological confirmation), the diagnosis of LBD was made and pharmacotherapy was revised. During hospitalization, pramipexole was excluded from therapy due to worsening of visual hallucinations, while levodopa/carbidopa was continued at a dose of 250/25 mg TID. Rivastigmine was also introduced at a dose of $3 \mathrm{mg}$ daily and divided into morning and evening applications as an acetylcholinesterase inhibitor recommended for the treatment of this type of dementia. Due to complex hallucinatory experiences and consequential affective engagement, clozapine was administered as an evening dose of $25 \mathrm{mg}$. Visual hallucinations then diminished and ceased, while the extrapyramidal symptoms were less pronounced, as well as cognitive fluctuations, with absence of delirium episodes and normalization of circadian rhythm.

\section{Discussion and Conclusion}

The variety of clinical presentation in the reviewed patient manifested as fluctuating cognitive impairments primarily in executive functioning with fluctuating delirious episodes and daily drowsiness, complex visual hallucinations, and atypical extrapyramidal motor symptoms. Episodes of oscillating syncope were present, as well as depressive mood and sensitivity to antipsychotics. A similar clinical state is described by
Wearne et al. ${ }^{9}$. Based on the clinical state and diagnostic workup performed, LBD was suspected, with difficult differentiation from other dementias, especially $\mathrm{AD}$ and $\mathrm{PDD}$, as well as their possible combinations ${ }^{10,11}$.

It is considered that the main feature of LBD is fluctuation of cognitive functions, which can be observed in most patients ${ }^{12}$. However, there are difficulties in consistent assessment of their presence ${ }^{3,13}$. Neuropsychological assessment of the presented patient revealed reduced memory capacity and learning ability, with reduced visual motor abilities and concentration disturbances, which is consistent with the data available ${ }^{14}$. However, although memory impairment occurs at an earlier stage of both disorders, the pattern of neuropsychological deficits in LBD differs from that in $\mathrm{AD}$ in terms of less pronounced memory impairment and more serious impairment of visual spatial orientation, attention, and executive functions ${ }^{13,15}$.

Furthermore, in our patient, as well as in around half of the patients diagnosed with LBD, well-formed visual hallucinations are present, which also are the most frequent psychiatric symptom of LBD. They may be accompanied by auditory hallucinations, delusions, anxiety, and behavioral disturbances, all of which distinguish this disease from dementia of another etiology, or from delirium induced by external causes ${ }^{16,17}$. The presence of visual hallucinations and cognitive impairment is associated with acetylcholinesterase deficiency, which is more pronounced in $\mathrm{LBD}$ than in $\mathrm{AD}^{18}$, and a correlation of visual hallucinations with the distribution of Lewy bodies in temporal lobes was also noted ${ }^{19}$.

The above-mentioned extrapyramidal symptoms in LBD are present in $25 \%$ to $50 \%$ of patients, and they are similar to those in Parkinson's disease with more pronounced postural instability, reduced facial expression, and less pronounced tremor, but with regard to clinical similarity between LBD and PDD, they often are differentiated by the use of already mentioned 'one-year rule ${ }^{3,20}$.

Depressive symptoms can be present in $33 \%$ to $50 \%$ of LBD patients, which was the case in our patient, which makes a greater percentage in relation to $\mathrm{AD}$ and similar percentage in relation to $\mathrm{PDD}^{17,21,22}$. Retrospective case-control studies indicate that the occurrence of depression or delirium before the diagnosis of dementia is more common in LBD than in $\mathrm{AD}^{7}$.

Spread of LBD related pathology to the brainstem and autonomic nervous system leads to orthostatic hy- 
potension and/or carotid sinus hypersensitivity, which consequently leads to syncope episodes that are more common in LBD than in $\mathrm{AD}^{6}$. Other symptoms such as constipation, REM sleep disturbances with daily drowsiness and restlessness during the night, hyposmia and postural vertigo appear several years prior to memory disorder in $\mathrm{LBD}^{23,24}$. Untimely urinary incontinence was observed in $\mathrm{LBD}$, unlike $\mathrm{AD}$, and it reflects an autonomic nervous system disorder ${ }^{25}$. Symptoms of autonomic dysfunction were present in our patient, which is consistent with the data reported by Horimoto et al., who established that all subjects exhibited some of the symptoms of autonomic dysfunction, and $62 \%$ experienced symptoms of severe autonomic dysfunction ${ }^{6}$.

In the available literature, there are abundant data on difficulties in differentiating among different types of dementia, LBD not being an exception. LBD could be misdiagnosed as PDD because of clinical manifestations ${ }^{26,27}$, as in the case presented, and often as $\mathrm{AD}^{26}$ or frontotemporal dementia ${ }^{28}$. Although a specific biomarker is still not available to confirm the LBD diagnosis, MRI findings in those involved, as in our $\mathrm{pa}^{-}$ tient, show a relatively preserved medial temporal lobe cortex with global cortical atrophy in comparison to patients with $\mathrm{AD}^{29}$, while structural changes shown by MRI in LBD compared to PDD are relatively identi$\mathrm{Cal}^{30}$. Furthermore, SPECT scans can be used to evaluate the integrity of dopaminergic nigrostriatal neurons, as well as to distinguish LBD from other forms of dementia. Namely, a possible indicative biomarker for LBD is a reduced intake of dopamine transporter into basal ganglia ${ }^{31}$, as confirmed in the case presented.

Regarding treatment, cholinesterase inhibitors may be used due to the already mentioned acetylcholine deficiency in $\mathrm{LBD}^{32-34}$, as confirmed in a case study ${ }^{35}$. They are effective in treating cognitive and behavioral symptoms, as well as visual hallucinations. We opted to use rivastigmine which improved the patient's condition. It is stated that more than $50 \%$ of patients have a strong reaction to antipsychotics in terms of hypersensitivity $^{8}$, especially with typical antipsychotics, which also have a higher risk of parkinsonism, as well as a higher potency of atypical ones, such as olanzapine and risperidone ${ }^{36}$. But, due to complex hallucinatory experiences in our patient, clozapine was introduced to treatment, a drug with a proven positive effect on $\mathrm{PDD}^{37}$. However, quetiapine is the recommended choice for antipsychotic treatment in LBD because of the more favorable side effect profile, although evidence for its efficacy is limited ${ }^{38}$. Also, a combination of levodopa/carbidopa was introduced for the purpose of reducing motor disturbances, which is consistent with the recommendations for treating $\mathrm{LBD}^{39}$.

Lewy body dementia should be taken in consideration whenever there are well-formed visual hallucinations, cognition fluctuations, parkinsonism or neuropsychological deficits at clinical presentation. Due to the differential diagnostic complexity and sensitivity to psychopharmacotherapy, further research is required to minimize deterioration of mental functions and daily functioning and to slow down the progression of the disease.

\section{References}

1. Moore DP, Puri BK. Neurodegenerative and movement disorders. In: Moore DP, Puri BK. Textbook of Clinical Neuropsychiatry and Behavioral Neuroscience, $3^{\text {rd }}$ edn. London: Hodder Arnold 2012;398-41.

2. Vann Jones SA, O'Brien JT. The prevalence and incidence of dementia with Lewy bodies: a systematic review of population and clinical studies. Psychol Med. 2014;44(4):673-83. doi: 10.1017/S0033291713000494

3. McKeith IG, Boeve BF, Dickson DW, et al. Diagnosis and management of dementia with Lewy bodies: Fourth Consensus Report of the DLB Consortium. Neurology. 2017;89(1): 88-100. doi: 10.1212/WNL.0000000000004058

4. Mrak RE, Griffin WS. Dementia with Lewy bodies: definition, diagnosis, and pathogenic relationship to Alzheimer's disease. Neuropsychiatr Dis Treat. 2007;3(5):619-25.

5. Byrne EJ, Lennox G, Lowe J, et al. Diffuse Lewy body disease: clinical features in 15 cases. J Neurol Neurosurg Psychiatry. 1989;52:709-17. doi: 10.1136/jnnp.52.6.709

6. Horimoto Y, Matsumoto M, Akatsu H, et al. Autonomic dysfunctions in dementia with Lewy bodies. J Neurol. 2003; 250(5):530-3. doi: 10.1007/s00415-003-1029-9

7. Auning E, Rongve A, Fladby T, et al. Early and presenting symptoms of dementia with Lewy bodies. Dement Geriatr Cogn Disord. 2011;32(3):202-8. doi: 10.1159/000333072

8. Ballard C, Grace J, McKeith I, et al. Neuroleptic sensitivity in dementia with Lewy bodies and Alzheimer's disease. Lancet. 1998;351(9108):1032-3. doi: https://doi.org/10.1016/S01406736(05)78999-6

9. Wearne D, Genetti A, Restifo S, et al. Are we missing dementia with Lewy bodies? A case report. Australas Psychiatry. 2018;26(4):381-3. doi: 10.1177/1039856218762305

10. Geser F, Wenning GK, Poewe W, et al. How to diagnose dementia with Lewy bodies: state of the art. Mov Disord. 2005; 20(12):S11-20. doi: 10.1002/mds.20535 
11. Chen JY, Stern Y, Sano M, et al. Cumulative risks of developing extrapyramidal signs, psychosis, or myoclonus in the course of Alzheimer's disease. Arch Neurol. 1991;48(11):1141-3. doi: 10.1001/archneur.1991.00530230049020

12. Tiraboschi P, Salmon DP, Hansen LA, et al. What best differentiates Lewy body from Alzheimer's disease in early-stage dementia? Brain. 2006;129(3):729-35. doi: 10.1093/brain/awh725

13. Merdes AR, Hansen LA, Jeste DV, et al. Influence of Alzheimer pathology on clinical diagnostic accuracy in dementia with Lewy bodies. Neurology. 2003;60:1586-90. doi: https://doi. org/10.1212/01.WNL.0000065889.42856.F2

14. Metzler-Baddeley C. A review of cognitive impairments in dementia with Lewy bodies relative to Alzheimer's disease and Parkinson's disease with dementia. Cortex. 2007;43(5):583-600. doi: https://doi.org/10.1016/S0010-9452(08)70489-1

15. Ballard C, Ayre G, O’Brien J. Simple standardised neuropsychological assessments aid in the differential diagnosis of dementia with Lewy bodies from Alzheimer's disease and vascular dementia. Dement Geriatr Cogn Disord. 1999;10:104-8. doi: 10.1159/000017109

16. McShane RH, Esiri MM, Joachim C, et al. Prospective evaluation of diagnostic criteria for dementia with Lewy bodies. Neurobiol Aging. 1998;19(4S):S204.

17. Mosimann UP, Rowan EN, Partington CE, et al. Characteristics of visual hallucinations in Parkinson disease dementia and dementia with Lewy bodies. Am J Geriatr Psychiatry. 2006;14 (2):153-60. doi: 10.1097/01.JGP.0000192480.89813.80

18. Tiraboschi P, Hansen LA, Alford M, et al. Cholinergic dysfunction in diseases with Lewy bodies. Neurology. 2000 Jan 25;54(2):407-11. doi: 10.1212/WNL.54.2.407

19. Harding AJ, Broe GA, Halliday GM. Visual hallucinations in Lewy body disease relate to Lewy bodies in the temporal lobe. Brain. 2002;125:391-403. doi: https://doi.org/10.1093/brain/ awf033

20. Burn DJ, Rowan EN, Minett T, et al. Extrapyramidal features in Parkinson's disease with and without dementia and dementia with Lewy bodies: a cross-sectional comparative study. Mov Disord. 2003;18:884-9. doi: 10.1002/mds.10455

21. Klatka LA, Louis ED, Schiffer RB. Psychiatric features in diffuse Lewy body disease: a clinicopathologic study using Alzheimer's disease and Parkinson's disease comparison groups. Neurology. 1996;47(5):1148-52. doi: 10.1212/WNL.47.5.1148

22. Peitl V, Karlović D, Štefanović M, et al. Serotonin transporter polymorphism in relation to depression. Alcohol Psychiatry Res. 2015;51(2):107-26.

23. Donaghy PC, McKeith IG. The clinical characteristics of dementia with Lewy bodies and a consideration of prodromal diagnosis. Alzheimers Res Ther. 2014;6(4):46. doi: 10.1186/ alzrt274

24. Grace J, Walker MP, McKeith IG. A comparison of sleep profiles in patients with dementia with Lewy bodies and Alzheimer's disease. Int J Geriatr Psychiatry. 2000;15:1028-33. doi: http://dx.doi.org/10.1002/1099-1166(200011)15:11<1028:: AID-GPS227>3.0.CO;2-E
25. Del-Ser T, Munoz DG, Hachinski V.Temporal pattern of cognitive decline and incontinence is different in Alzheimer's disease and diffuse Lewy body disease. Neurology. 1996;46:682-6. doi: https://doi.org/10.1212/WNL.46.3.68

26. Khotianov N, Singh R, Singh S. Lewy body dementia: case report and discussion.J Am Board Fam Pract. 2002;15(1):50-4.

27. de Almondes KM, Holanda Junior FWN, Matos Leonardo $\mathrm{ME}$, et al. Dementia with Lewy bodies: a case report. Ann Neurodegener Dis. 2016;1(1):1003.

28. Nagahama Y, Fukui T. Dementia with Lewy bodies presenting as frontotemporal dementia phenotype. Psychogeriatrics. 2019; 19(5):505-9. doi: 10.1111/psyg.12405

29. Barber R, McKeith IG, Ballard C, et al. A comparison of medial and lateral temporal lobe atrophy in dementia with Lewy bodies and Alzheimer's disease: magnetic resonance imaging volumetric study. Dement Geriatr Cogn Disord. 2001;12(3): 198-205. doi: 10.1159/000051258

30. Watson R, Blamire AM, O'Brien JT. Magnetic resonance imaging in Lewy body dementias. Dement Geriatr Cogn Disord. 2009;28(6):493-506. doi: 10.1159/000264614

31. Tateno M, Kobayashi S, Saito T. Imaging improves diagnosis of dementia with Lewy bodies. Psychiatry Investig. 2009;6(4):23340. doi: 10.4306/pi.2009.6.4.233

32. Stinton C, McKeith I, Taylor JP, et al. Pharmacological management of Lewy body dementia: a systematic review and meta-analysis. Am J Psychiatry.2015;172(8):731-42. doi: 10.1176/ appi.ajp.2015.14121582

33. McKeith IG, Wesnes KA, Perry E, et al. Hallucinations predict attentional improvements with rivastigmine in dementia with Lewy bodies. Dement Geriatr Cogn Disord. 2004;18:94-100. doi: $10.1159 / 000077816$

34. Wesnes KA, McKeith I, Ferrara R, et al. Effects of rivastigmine on cognitive function in dementia with Lewy bodies: a randomised placebo controlled international study using the cognitive drug research computerised assessment system. Dement Geriatr Cogn Disord. 2002;13(3):183-92. doi: 10.1159/0000 48651

35. Nour JM, Chouliaras L, Hickey L. High dose rivastigmine in the symptom management of Lewy body dementia. BMJ Case Rep. 2016 Nov 29;2016:bcr2016217240. doi: 10.1136/bcr2016-217240

36. Armstrong MJ, Weintraub D. The case for antipsychotics in dementia with Lewy bodies. Mov Disord Clin Pract. 2017; 4(1):32-5. doi: 10.1002/mdc3.12383

37. Lee HB, Hanner JA, Yokley JL, et al. Clozapine for treatmentresistant agitation in dementia. J Geriatr Psychiatry Neurol. 2007;20:178-82. doi: 10.1177/0891988707303335

38. Kurlan R, Cummings J, Raman R, et al. Quetiapine for agitation or psychosis in patients with dementia and parkinsonism. Neurology. 2007;68:1356-63. doi: 10.1212/01.wnl.00002600 60.60870 .89

39. Molloy S, McKeith IG, O'Brien JT, et al. The role of levodopa in the management of dementia with Lewy bodies. J Neurol Neurosurg Psychiatry. 2005;76:1200-3. doi: 10.1136/jnnp. 2004.052332 


\section{Sažetak}

\section{ENIGMA DEMENCIJE LEWYJEVIH TJELEŠACA: PRIKAZ SLUČAJA}

\section{Orlović, M. Bartolović, K. Marušić, D. Vlahović, I. Šiško Markoš, D. Karlović i V. Peitl}

Demencija Lewyjevih tjelešaca je neurodegenerativna bolest i drugi najčešći uzročnik demencije u starijih osoba. Zbog složenosti kliničke slike često se pogrešno dijagnosticira i nerijetko zamijeni s drugim demencijama, što dovodi do primjene neodgovarajuće terapije, a time i pogoršanja stanja bolesnika. Prikazujemo slučaj bolesnika u dobi od 71 godine kod kojega se klinička slika postupno prezentirala složenim vizualnim halucinacijama, atipičnim ekstrapiramidnim motoričkim ispadima, fluktuirajućim kognitivnim smetnjama uz delirantne epizode i oscilirajuće sinkope. Kod bolesnika je zabilježeno depresivno raspoloženje, narušeno svakodnevno funkcioniranje i osjetljivost na psihofarmake. Provedena je opširna dijagnostička obrada uz neuropsihologijsko testiranje i primjenu jednofotonske emisijske tomografije. Na temelju kliničke slike i diferencijalno dijagnostičke obrade posumnjalo se na demenciju Lewyjevih tjelešaca. Raspravljamo o važnosti uzimanja u obzir cjelokupne kliničke slike i dijagnostičke obrade te primjeni odgovarajućeg liječenja u svrhu prevencije progresije bolesti i pogoršanja psihičkih funkcija bolesnika.

Ključne riječi: Demencija Lewyjevih tjelešaca; Kognitivno oštećenje; Halucinacije; Parkinsonov sindrom; Inhibitori kolinesteraze; Demencija 